\title{
Diffuse Flesh Browning in 'Honeycrisp' Apple Fruit is Associated with Low Temperatures during Fruit Growth
}

\author{
Cindy B.S. Tong ${ }^{2}$, Hsueh-Yuan Chang, Jennifer K. Boldt ${ }^{1}$, \\ and Yizhou B. Ma \\ Department of Horticultural Science, University of Minnesota, 1970 Folwell \\ Avenue, Saint Paul, MN 55108
}

Jennifer R. DeEIl

Ontario Ministry of Agriculture, Food and Rural Affairs, Simcoe, Ontario, Canada, N3Y 4N5 Renae E. Moran
Department of Plant, Soil and Environmental Sciences, University of Maine,
P.O. Box 179, Monmouth, ME 04259

Gaétan Bourgeois and Dominique Plouffe

Horticultural Research and Development Centre, Agriculture and Agri-Food Canada, 430 Boulevard Gouin, Saint-Jean-sur-Richelieu, QC, Canada, J3B 3E6

Additional index words. Malus $\times$ domestica, disorder, storage, sugars, weather

\begin{abstract}
Multiple types of flesh browning can occur as storage disorders in 'Honeycrisp' apple (Malus $\times$ domestica Borkh.) fruit. Predicting its occurrence is hindered by differing definitions of the types of browning, incomplete understanding of their etiologies, and difficulty in assessing harvest maturity of 'Honeycrisp' fruit. In 2013, of 'Honeycrisp' fruit grown, harvested over multiple weeks, and stored in Maine, Minnesota, Ontario, and Quebec, only the Quebec fruit developed diffuse flesh browning. A detailed comparison showed that the Quebec fruit differed in size, but not in other quality attributes, from fruit of the other locations. The Quebec fruit experienced lower temperatures during active fruit growth and were increasing in cell size up to harvest. Analyses of climate data from 2009 to 2015 indicated that accumulated growing degree-days (GDD) 50-60 day after full bloom (DAFB) could account for $31 \%$ of the variation in diffuse flesh browning, and seasonal GDD $<\mathbf{5 0 0}$ are associated with a greater likelihood of injury. Fruit that exhibited diffuse flesh browning had higher magnesium and lower fructose levels than unaffected fruit. As these measurements were made after browning was assessed, the timing of the onset of these characteristics in relation to browning cannot be determined.
\end{abstract}

Multiple types of flesh browning can occur as storage disorders in 'Honeycrisp' apple (Malus $\times$ domestica) fruit. Three of the browning disorders that occur within the cortex have been previously described as "soggy breakdown" (Watkins et al., 2005),

Received for publication 14 July 2016. Accepted for publication 17 Aug. 2016.

This project received funding from the Minnesota Agricultural Experiment Station for MN 21-065, University of Minnesota Undergraduate Research Opportunity Program, and Maine Agricultural and Forest Experiment Station Project ME031404.

We thank Randolph Beaudry and Chet Miller for providing some samples, Chris Walsh for pointing out literature, Ted Joe and Deborah Samac for use of their HPLC, John Krause and Kai-Ting Fan for technical support, and Matthew Clark and James Luby for reading manuscript drafts.

${ }^{1}$ Current address: USDA-ARS, Greenhouse Production Research Group, 2801 W. Bancroft St., Mail Stop 604, Toledo, OH 43606.

${ }^{2}$ Corresponding author. E-mail: c-tong@umn.edu. "controlled atmosphere (CA) injury" (Contreras et al., 2014), and "senescent breakdown" (Prange et al., 2011). A fourth type of diffuse cortical browning occurs, that is distinguished from soggy breakdown by lack of a defined border between affected and healthy tissue and from senescent breakdown by a lack of browning in the vascular tissue. This diffuse flesh browning disorder resembles previously described cortical browning disorders, but conditions that cause it remain unclear. A number of similar cortical browning disorders, called "internal breakdown," "internal browning," and "low-temperature breakdown," have been described for other apple cultivars (Faust and Williams, 1969; Smock, 1977; Meheriuk et al., 1994), but it is not clear if the diffuse flesh browning of 'Honeycrisp' can be classified as one of these low storage temperature disorders. Confusion is partly due to the use of different names for the same disorder. In addition, identification and classification of browning disorders are hindered by differing definitions of the types of browning, incomplete understanding of their etiologies, variation in visual symptoms among different cultivars, and difficulty in assessing harvest maturity of 'Honeycrisp' fruit.

In 2009, widespread cortex browning like that depicted in DeLong et al. (2006) was observed in 'Honeycrisp' fruit grown in Minnesota. Apple growers were alarmed by this disorder, as it had not been observed in Minnesota, except in 2004 at one orchard, and wanted some way to predict the occurrence of this and other browning disorders. Maturity and postharvest conditions that lead to soggy breakdown in 'Honeycrisp' have been previously documented (DeLong et al., 2006; Moran et al., 2009; Watkins et al., 2005). Lack of prediction and classification of 'Honeycrisp' browning disorders is exacerbated by the difficulty of judging harvest maturity, as the usual apple harvest indices, such as autocatalytic ethylene production, decrease in firmness, and gradual increase in starch index, are often not exhibited by 'Honeycrisp' fruit (Watkins et al., 2005).

In 'Cripps Pink' fruit, three different types of flesh browning have been discerned along with the conditions that increase their occurrence (James and Jobling, 2009). One type is due to carbon dioxide accumulation during CA storage. Another type of browning, radial browning, occurs in the vascular tissue, is highest at the stem end of the fruit, and is associated with fractured walls of cells adjoining vascular tissue, but no damage to cortical tissue. The third type of browning, diffuse browning, occurs throughout the cortex, is highest at the ends and least in the middle of fruit, and is associated with collapse of cortical cells and presumably disruption of middle lamella. Radial browning and diffuse browning in 'Cripps Pink' have not been observed at harvest, and reach "commercially significant levels following 4 months of storage." Increasing storage temperature from 0 to $3{ }^{\circ} \mathrm{C}$ decreases their incidence.

Many factors can affect the incidence and degree of severity of the cortical browning storage disorders seen in apple fruit, especially maturity of the fruit, with less mature fruit being more affected (Faust and Williams, 1969). Thus, any environmental factor that delays maturity, such as shading, cool weather before harvest, and heavy crop load, increases severity of the disorder. However, Moggia et al. (2015), from an analysis of 6 years of data, concluded that radial browning in 'Cripps Pink' could best be predicted using growing degree hours (GDH) and fruit firmness at harvest, with more mature fruit being more susceptible to radial browning. Diffuse browning could best be predicted by GDH and fruit background color at harvest, but not by starch index or fruit firmness, so fruit maturity influenced diffuse browning less than radial browning in 'Cripps Pink'. Greater incidence of internal browning of 'Empire' and 'Ambrosia' are associated with lower internal ethylene concentration (IEC), 
whereas core browning is associated with greater IEC in 'Ambrosia', but not 'Empire' (Ehsani-Moghaddam and DeEll, 2013). Effects of temperature during the growing season and fruit maturity on flesh browning therefore may depend on the specific type of browning. Effect of maturity on occurrence of storage disorders is useful in classification and understanding their cause and predicting development. However, as previously stated, determining maturity effects on disorders in 'Honeycrisp' is difficult because maturity of 'Honeycrisp fruit is difficult to discern.

Low temperature and fewer degree-days during the growing season are associated with increased risk of flesh browning disorders in a number of cultivars (James et al., 2010; Lau, 1998; Sharples, 1975). For example, decreased severity of low-temperature breakdown in 'Bramley's Seedling' apples is associated with low rainfall and high temperatures 4 weeks before harvest, as well as delayed harvest in the United Kingdom (Sharples, 1975). On the other hand, the critical period for low-temperature breakdown susceptibility in 'Cox's Orange Pippin' fruit is between the 7th and 10th week after full bloom or the month of July for fruit grown in the United Kingdom (Sharples, 1975). Low variation in diurnal temperatures in the $60 \mathrm{~d}$ before harvest is associated with increased risk of development of both radial and diffuse browning in 'Cripps' Pink' in Australia (James et al., 2010). Previous research on soft scald of 'Honeycrisp' indicates periods of environmental sensitivity in the month after full bloom (Lachapelle et al., 2013) and the month before harvest (Moran et al., 2009) are important in its development in North America. Environmental conditions during sensitive stages of fruit growth are thought to influence storage disorders when they alter cell size, tissue density, and gas diffusivity of the skin and cuticle (Elgar et al., 1999; James et al., 2010; Lachapelle et al., 2013).

The mineral composition of fruit is also implicated in the development of flesh browning disorders. In 'Cripps Pink', negative correlations occur between diffuse flesh browning and calcium to potassium and calcium to magnesium ratios in fruit (James and Jobling, 2009). Flesh breakdown in 'Gala' is positively correlated with $\mathrm{K}, \mathrm{Mg}, \mathrm{Na}$, and $\mathrm{Cu}$ in fruit at harvest (Johnson, 2000). In 'McIntosh' and 'Cox's Orange Pippin', low-temperature storage disorders are associated with low P concentration in fruit (Webster and Lidster, 1986), and increasing fruit $\mathrm{P}$ reduces low-temperature breakdown (Johnson and Yogaratnam, 1978). Variation in mineral concentration may be indirectly related to storage disorders through factors that influence fruit size such as light (Jackson et al., 1977) and crop load (Telias et al., 2006). It is not clear if fruit size is a factor in the occurrence of diffuse flesh browning.

The "low-temperature" disorders in some apple cultivars are associated with cold storage and disruption of carbohydrate metabolism. These disorders are complex, and often comprised of different types of injury. Internal breakdown in 'Jonathan' and other apple cultivars is accompanied by an accumulation of acetaldehyde (Faust and Williams, 1969). Low-temperature breakdown, on the other hand, is accompanied by an accumulation of oxaloacetate. These compounds are formed from sorbitol and sucrose translocated from leaves to fruit (Berüter et al., 1997). Low-temperature breakdown is associated with sorbitol accumulation in cold storage in several cultivars, but this may be a co-occurring phenomenon of cold storage rather than a causal relationship (Fidler and North, 1970). At 8 weeks after full bloom, starch concentration within the fruit nears peak production, glucose and sorbitol levels fall, and fructose and sucrose levels increase (Zhang et al., 2010). Little information is available regarding carbohydrates involved in earlier fruit developmental stages, such as during the transport of sugars from leaves to fruit during active fruit growth

This study was undertaken to determine how the environmental factors of temperature and precipitation, as well as physiological disruptions are associated with diffuse flesh browning of cold-stored 'Honeycrisp' fruit, and to what extent that browning is

Table 1. Years of harvests, locations from which fruit were harvested, and types of data collected in this study.

\begin{tabular}{lcc}
\hline $\mathrm{Yr}$ & \multicolumn{1}{c}{ Locations } & Data collected \\
\hline 2009 & Commercial orchard, Sparta, Michigan & Elemental analyses \\
& $43^{\circ} 6^{\prime} 12^{\prime \prime} \mathrm{N}, 85^{\circ} 42^{\prime} 1^{\prime \prime} \mathrm{W}$ & \\
& Horticultural Research Center, University of Minnesota, & \\
& Victoria, $44^{\circ} 51^{\prime} 30^{\prime \prime} \mathrm{N}, 93^{\circ} 39^{\prime} 41^{\prime \prime} \mathrm{W}$ &
\end{tabular}

2009-15 Locations as listed below for 2013

2013 Highmoor Farm, University of Maine, Monmouth, $44^{\circ} 13^{\prime} 51^{\prime \prime} \mathrm{N}, 70^{\circ} 4^{\prime} 5^{\prime \prime} \mathrm{W}$ and $44^{\circ} 14^{\prime} 17^{\prime \prime} \mathrm{N}, 70^{\circ} 3^{\prime} 43^{\prime \prime} \mathrm{W}$

Weather and diffuse browning

Fruit size, maturity measurements, elemental analyses, sugars

Horticultural Research Center, University of Minnesota, Victoria

Commercial orchards in Simcoe, Ontario, $42^{\circ} 52^{\prime} 44^{\prime \prime} \mathrm{N}, 80^{\circ} 15^{\prime} 22.6^{\prime \prime} \mathrm{W}$ and $42^{\circ} 49^{\prime} 22^{\prime \prime} \mathrm{N}, 80^{\circ} 20^{\prime} 3^{\prime \prime} \mathrm{W}$

Institute for Research and Development in Agroenvironment, Saint-Bruno-de-Montarville, Quebec, $45^{\circ} 32^{\prime} 29^{\prime \prime} \mathrm{N}, 73^{\circ} 20^{\prime} 26^{\prime \prime} \mathrm{W}$

2014-15 Commercial orchard, Minnesota, 44 $25^{\prime} 10.5^{\prime \prime} \mathrm{N}$ Weather, diffuse browning, $92^{\circ} 13^{\prime} 17^{\prime \prime} \mathrm{W}$ and $44^{\circ} 24^{\prime} 22^{\prime \prime} \mathrm{N}, 92^{\circ} 9^{\prime} 9^{\prime \prime} \mathrm{W} \quad$ sugar, and elemental analyses

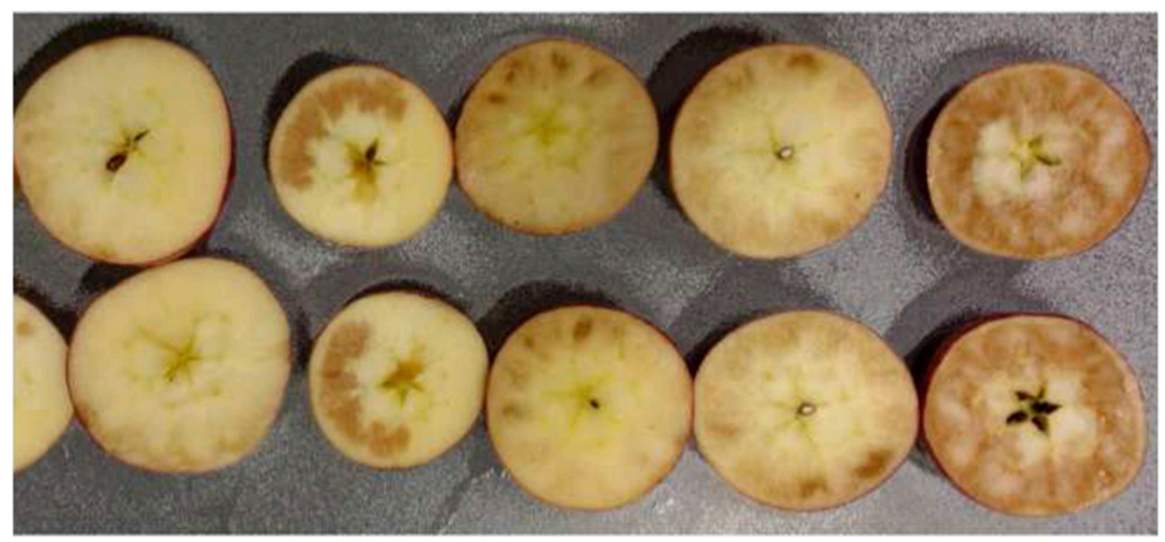

Fig. 1. Examples of flesh browning observed in Minnesota fruit after 8 weeks of storage at $0{ }^{\circ} \mathrm{C}$. Shown from left to right are 1) little diffuse browning, 2) soggy breakdown, 3) and 4) diffuse browning with soggy breakdown, and 5) severe diffuse browning. 
was beginning to develop. In Minnesota, the first harvest occurred when fruit background color changed from green to yellow based on subjective visual assessments. In Ontario and Quebec, the first harvest occurred when the starch index neared 4.5 and 6 , respectively, and background color started to change from green to yellow based on subjective visual assessments. The first harvest dates were Sept. 11, Oct. 2, Sept. 13, and Sept. 20, for Maine, Minnesota, Ontario, and Quebec, respectively. Fruit were stored for 8 weeks at $0 \pm 1{ }^{\circ} \mathrm{C}$ in Maine, Minnesota, and Ontario, and at $3 \pm$ $1{ }^{\circ} \mathrm{C}$ in Quebec. Atmospheric conditions in cold storage were not manipulated. Weather and diffuse browning data were collected from the same locations in 2009-15, and fruit were harvested and stored at the individual locations as for 2013. Thirty to forty fruit from each harvest date in Maine, Ontario, and Quebec were packed in Styrofoam boxes with frozen ice-gel packs at the originating location and shipped overnight to Minnesota for cell size, starch, and dry matter measurements.

In 2014, fruit were also collected from two orchards (at least 100 fruit per orchard) of a commercial operation in southeastern Minnesota. The two orchards are located only $6.4 \mathrm{~km}$ apart; have similar topography, orientation toward a lake, and elevation; and are managed in the same way. 'Honeycrisp' trees in both orchards were on the same rootstock, given the same fertility regime, and thinned so that crop loads were similar. Fruit were harvested when background color changed from green to yellow based on subjective visual assessments.

In 2009, 'Honeycrisp' fruit grown in a commercial orchard in Michigan and at the University of Minnesota orchard that did and did not exhibit diffuse flesh browning after 2 months of storage at $0{ }^{\circ} \mathrm{C}$ were obtained. Mesocarp tissue of 20 fruit per browning type was separated from other parts of the fruit and freeze-dried for later elemental analyses. Also, data were collected in 2009, 2014, and 2015 fruit grown at a commercial orchard in Minnesota. In 2014 and 2015, three lots of 10-15 fruit per lot from this orchard were stored at $0{ }^{\circ} \mathrm{C}$ and scored for diffuse flesh browning after 2 months. Mesocarp tissue with and without diffuse flesh browning were frozen at $-40{ }^{\circ} \mathrm{C}$ for subsequent juice extraction and elemental analyses.

Weather data. Historical daily weather records were obtained from orchard temperature sensors, the U.S. National Weather Service (http://www.weather.gov/), or the Government of Canada website (https://weather.gc.ca). GDD were calculated by averaging the daily maximum and minimum temperatures and subtracting $10{ }^{\circ} \mathrm{C}\left(10^{\circ} \mathrm{C}\right.$ base $)$ starting from full bloom.

Fruit and cell size measurements. In 2013, diameters of 50-100 fruit were measured about biweekly starting 34 DAFB in Maine, weekly starting 30 DAFB in Minnesota, and every 7-14 d starting 60 and 65 DAFB in Ontario and Quebec, respectively. Cell sizes of three fruit harvested 60,90, and 120 DAFB from each location were measured. Sections of $5 \mathrm{~mm} \times 10 \mathrm{~mm}$ were cut by hand from fruit cortex tissue and viewed under a Leitz Laborlux K microscope (Leitz, Wetzlar, Germany) equipped with a SPOT Insight 4 Digital Camera (SPOT Insight QE; Diagnostic Instruments, Sterling Heights, MI). Three images of $\times 100$ magnification were photographed for each fruit. Cell sizes were measured with ImageJ software.

Maturity determinations. Quality attributes of 'Honeycrisp' fruit measured at harvest included fruit weight, starch index, firmness, soluble solids content (SSC), and titratable acidity (TA). Ten fruit from each harvest and location were used for the assessments. After initial assessments were made, fruit were peeled and $20 \mathrm{~g}$ of mesocarp tissue per replicate fruit were placed into $-40{ }^{\circ} \mathrm{C}$ storage for further analysis of dry matter percentage and carbohydrate content.

Starch index was rated using the starchiodine test as described by Blanpied and Silsby (1992). Flesh firmness was measured by a puncture test. This was done using a mechanized pressure tester in Maine (EPT-1; Lake City Tech, Products, Lake City, Canada), a drill press-mounted penetrometer (FT30 from Wagner in Minnesota and FT327 from Effigi
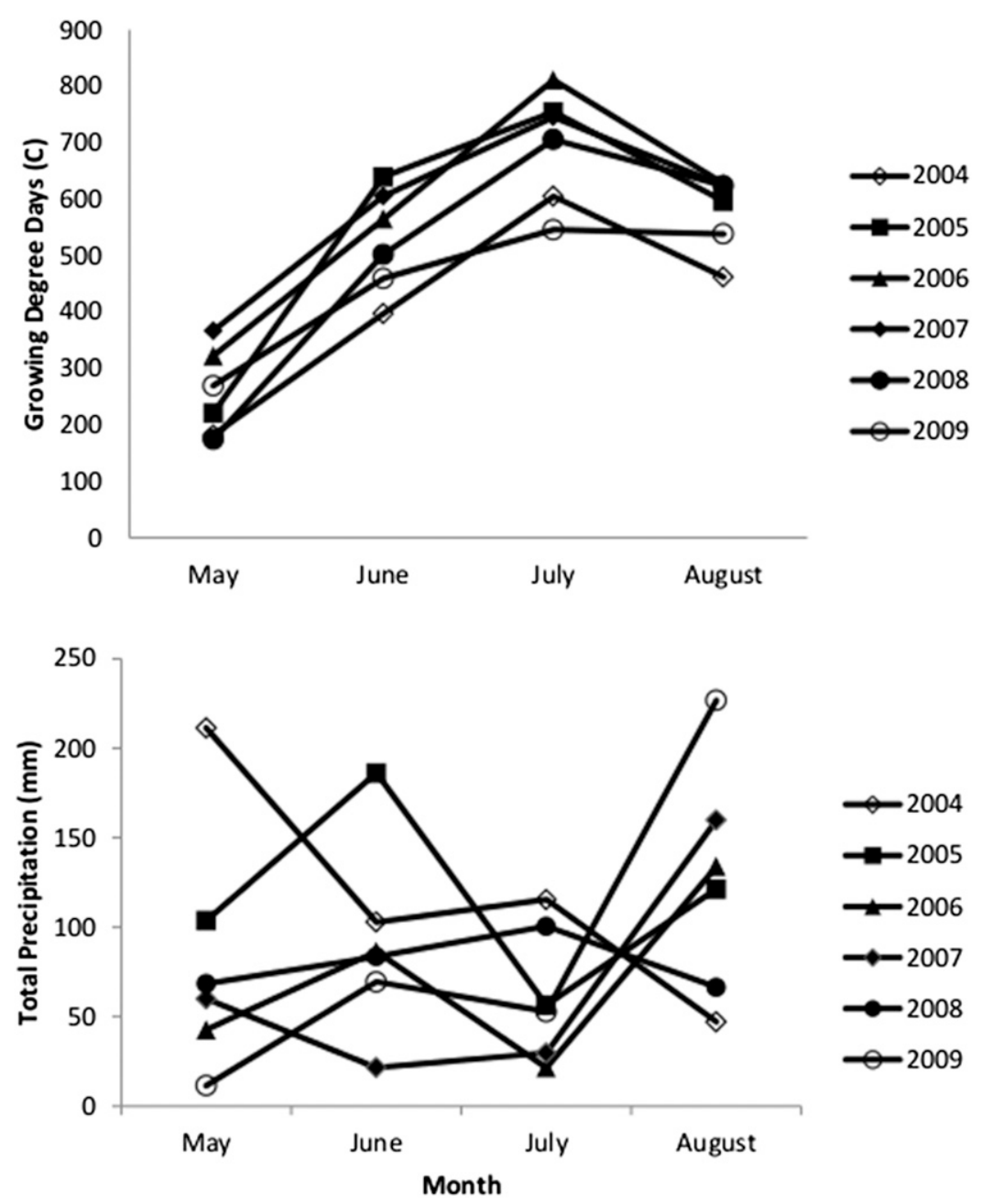

Fig. 2. Monthly growing degree-days $\left(10^{\circ} \mathrm{C}\right.$ base $)$ and precipitation from May to August in Chanhassen, MN, from 2004 to 2009.

Table 2. Maximum percentage of diffuse flesh browning (FB) observed among three harvests and growing degree-days (GDD) $60 \mathrm{~d}$ after full bloom during 2009-15 at six orchard locations.

\begin{tabular}{|c|c|c|c|c|c|c|c|c|c|c|c|c|c|c|}
\hline \multirow[b]{2}{*}{$\mathrm{Yr}$} & \multicolumn{2}{|c|}{2009} & \multicolumn{2}{|c|}{2010} & \multicolumn{2}{|c|}{2011} & \multicolumn{2}{|c|}{2012} & \multicolumn{2}{|c|}{2013} & \multicolumn{2}{|c|}{2014} & \multicolumn{2}{|c|}{2015} \\
\hline & FB & GDD & FB & $\overline{G D D}$ & $\overline{\mathrm{FB}}$ & GDD & FB & GDD & $\overline{\mathrm{FB}}$ & GDD & & GDD & FB & $\overline{\mathrm{GD}}$ \\
\hline Site & $(\%)$ & $60 \mathrm{~d}$ & $(\%)$ & $60 \mathrm{~d}$ & $(\%)$ & $60 \mathrm{~d}$ & $(\%)$ & $60 \mathrm{~d}$ & $(\%)$ & $60 \mathrm{~d}$ & FB (\%) & $60 \mathrm{~d}$ & $(\%)$ & $60 \mathrm{~d}$ \\
\hline Maine & & 356 & 15 & 458 & 0 & 565 & 0 & 528 & 0 & 586 & 7 & 579 & 40 & 485 \\
\hline Minnesota & & 513 & no crop & 449 & 0 & 664 & no crop & 417 & 7 & 627 & 13 & 604 & & 440 \\
\hline Ontario & 12 & 400 & 0 & 445 & 0 & 619 & 0 & 476 & 0 & 578 & 0 & 498 & 35 & 435 \\
\hline Quebec & 0 & 413 & 0 & 482 & 0 & 602 & 0 & 549 & 20 & 465 & 7 & 550 & 7 & 513 \\
\hline PH1 & 57 & 460 & & & & & & & & & 13 & 639 & 23 & 458 \\
\hline PH2 & & & & & & & & & & & 33 & 602 & 10 & 420 \\
\hline
\end{tabular}

Blank cells indicate that no data were available for those years from those locations. $\mathrm{PH} 1$ and $\mathrm{PH} 2$ denote the two orchards of a commercial operation in southeastern Minnesota. 
in Quebec), and an electronic Fruit Texture Analyzer (GÜSS, South Africa) in Ontario. All penetrometers were equipped with an 11-mm tip. Readings were taken on two opposite sides of the equatorial area of a fruit and averaged. Total SSC was determined with a refractometer (PR-100 in Maine, ATC-1E in Minnesota, BRX-242 in Ontario, and PAL-1 in Quebec; Atago Co. Ltd., Tokyo, Japan). TA was measured using juice expressed from cortex tissue, diluted, and titrated with $0.1 \mathrm{~m}$ sodium hydroxide to $\mathrm{pH}$ 8.1. TA was expressed as malic acid equivalents. For dry matter determinations, $10 \mathrm{~g}$ frozen sample was dried in a vacuum oven at $95^{\circ} \mathrm{C}$ and $75 \mathrm{~mm} \mathrm{Hg}$ for $4 \mathrm{~h}$ until a constant weight was obtained. Dry matter was expressed as a percentage of fresh weight.

Diffuse flesh browning assessments. Thirty fruit from each location and harvest were stored at $0 \pm 1{ }^{\circ} \mathrm{C}$ in Maine, Minnesota, and Ontario (to maximize induction of the disorder), and at $3 \pm 1{ }^{\circ} \mathrm{C}$ in Quebec for 8 weeks from each harvest. After storage, fruit were held at room temperature. Half of the fruit was screened for flesh browning after $1 \mathrm{~d}$, while the other half was screened after $7 \mathrm{~d}$ from removal from storage. Only presence or absence, and not degree, of diffuse flesh browning for each fruit was recorded.

Carbohydrate measurements. Carbohydrates were measured in apple juice pressed using a handheld garlic press from previously frozen mesocarp tissue held at $-40{ }^{\circ} \mathrm{C}$. To remove solids, the juice was centrifuged at $8160 g_{\mathrm{n}}$ for $5 \mathrm{~min}$ at room temperature. Before analysis, the juice was passed through a $0.2-\mu \mathrm{m}$ porosity syringe filter (Pall Life Science, Port Washington, NY) and diluted 1:1 (v/v) with distilled water. Quantitative sugar analysis was conducted following the method of Liu et al. (2006). Sucrose, fructose, glucose, and sorbitol were measured using a SpectraSYSTEM high-performance liquid chromatography system (Thermo Finnigan, San Jose, CA) equipped with a refractive index detector and a Capcell-Pak-NH2 column $(250 \mathrm{~mm} \times 4.6 \mathrm{~mm})$. Sugars were separated using an acetonitrile:water $(80: 20, \mathrm{v} / \mathrm{v})$ mobile phase, at a flow rate of $1.0 \mathrm{~mL} / \mathrm{min}$, and a column temperature of $35^{\circ} \mathrm{C}$. In the 2013 study, 10 individual fruit for each location and harvest date, with three technical replicates per

Table 3. Analysis of variance of factors affecting diffuse flesh browning of 'Honeycrisp' fruit from 2009 to 2015 in Maine, Minnesota, Ontario, and Quebec.

\begin{tabular}{lccccc}
\hline Source & $\begin{array}{c}\text { Sum of } \\
\text { squares }\end{array}$ & $\begin{array}{c}\text { Mean sum } \\
\text { df }\end{array}$ & $\begin{array}{c}\mathrm{F} \\
\text { of squares }\end{array}$ & $\begin{array}{c}P \\
\text { statistic }\end{array}$ \\
value \\
\hline Location & 248 & 3 & 82.7 & 0.46 & 0.71 \\
Year & 104.5 & 1 & 104.5 & 0.58 & 0.46 \\
50 DAFB & 662.8 & 1 & 662.8 & 3.71 & 0.08 \\
55 DAFB & 429 & 1 & 429 & 2.40 & 0.15 \\
60 DAFB & $1,030.6$ & 1 & $1,030.6$ & 5.77 & 0.03 \\
65 DAFB & 11.1 & 1 & 11.1 & 0.06 & 0.81 \\
75 DAFB & 92.6 & 1 & 92.6 & 0.52 & 0.48 \\
Location: & 447.4 & 3 & 149.1 & 0.84 & 0.50 \\
$\quad$ year & & & & & \\
Error & $2,320.4$ & 16 & 178.5 & & \\
Total & $5,346.4$ & 28 & & & \\
\hline DAFB & & & & &
\end{tabular}

$\mathrm{DAFB}=$ days after full bloom. sample, were tested. For analyses using fruit from the commercial Minnesota orchard, 10 fruit with and 10 without diffuse flesh browning were assayed in 2014 and 2015.

Elemental analyses. Mesocarp tissue was frozen at $-40{ }^{\circ} \mathrm{C}$ and freeze-dried for at least $48 \mathrm{~h}$. Freeze-dried tissue was ground with a mortar and pestle or coffee grinder, and analyzed via inductively coupled plasma-optical emission spectrometry by the University of Minnesota Research Analytical Laboratory for various elements at a $485{ }^{\circ} \mathrm{C}$ ashing temperature. Ten samples per location and disorder type were analyzed.

Statistical analyses. All statistical analyses were done using RStudio version 0.99.486 (RStudio Team, 2015). Analysis of variance (ANOVA) was used to examine contributions to diffuse flesh browning variation by different variables. Separation of means analyses, when applicable, was done using Tukey's honestly significant difference tests. Welch two-sample $t$ tests were used to determine differences among mean values. Associations between paired variables were assessed using Pearson's correlation test. For simplicity, analyses used data from one orchard per location (the same orchard in Maine and Ontario for all analyses), unless stated otherwise.

\section{Results and Discussion}

In 2009 , flesh browning was widely reported throughout Minnesota, in contrast to 2004, when only one commercial orchard reported its occurrence. Various disorders, such as "soggy breakdown" (Fig. 1, second from left) as described by DeLong et al. (2006), lens-shaped cavities (Fig. 1, third from left) as described by Contreras et al. (2014), and "diffuse browning" (Fig. 1, far right), as described by James and Jobling (2009) for 'Cripps Pink' were observed. For this particular study, only fruit with diffuse browning were used.

Preliminary analysis of weather data from 2004 to 2009 for Chanhassen, MN, showed that accumulated GDD in July and August were lower in 2004 and 2009 compared with other years (Fig. 2). There was no discernable difference in accumulated precipitation among years, so no association between browning and precipitation was apparent with 'Honeycrisp' fruit as with 'Bramley's

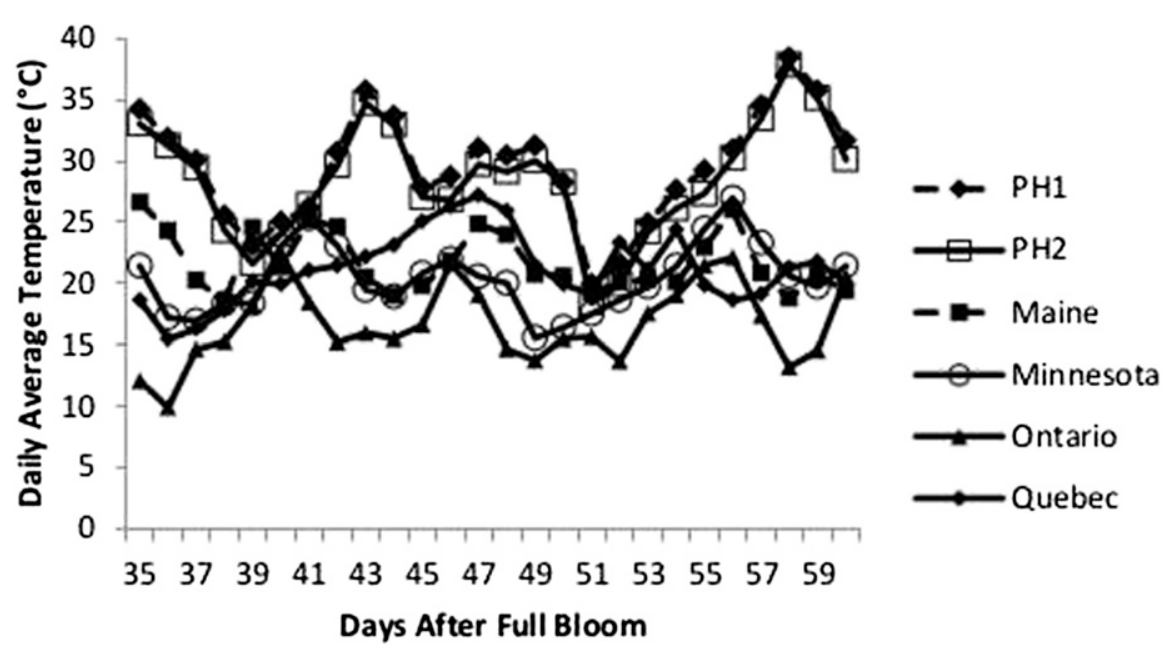

Fig. 3. Mean daily air temperatures at multiple orchard locations in 2014. PH1 and P2 are the designations for the two orchards of a commercial operation in Minnesota.

Mean Fruit Size

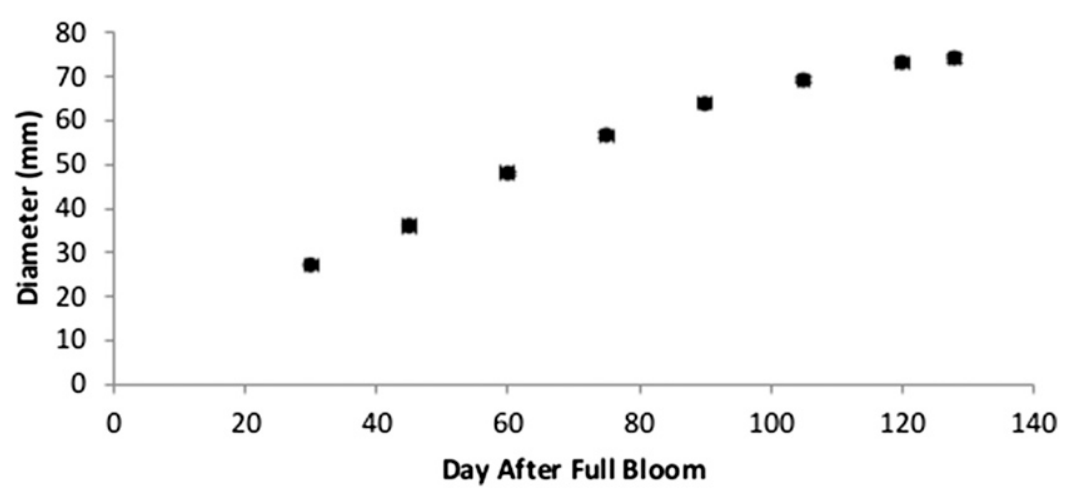

Fig. 4. Mean diameter of 'Honeycrisp' fruit growing in the University of Minnesota orchard in 2013. SES are smaller than the data points. 
Seedling' fruit (Sharples, 1975). These data led to the hypothesis that 'Honeycrisp' fruit diffuse flesh browning, like 'Cox's Orange Pippin' (Sharples, 1975), is due to low July temperatures.

In 2013, only 'Honeycrisp' fruit at the Quebec orchard developed greater than 10\% flesh browning after storage (Table 2), and only for the third harvest. Flesh browning in fruit from either the first or second harvest was $7 \%$. Maximal flesh browning could not be related to harvest date for all years shown in Table 2 as those data were not always recorded. The flesh browning observed in 2013 was similar in appearance to 'Cripps Pink' diffuse browning (James and Jobling, 2009). The environmental features distinguishing the Quebec orchard from the other locations in 2013 were earliest full bloom date and smallest accumulated GDD between full bloom and first harvest. It was observed that the minimum temperature in the Quebec orchard dipped below $15^{\circ} \mathrm{C}$ several times in July, and the maximum temperature dropped below $20^{\circ} \mathrm{C}$ on July 24 , all around 70 DAFB. The maximum temperature also dropped below $20{ }^{\circ} \mathrm{C}$ in the Minnesota orchard on July 27 (63 DAFB), and 7\% of 'Honeycrisp' fruit at that orchard exhibited diffuse flesh browning. Maximum daily temperatures 4 weeks before harvest were all $\approx 30{ }^{\circ} \mathrm{C}$ in Maine and Minnesota, $26{ }^{\circ} \mathrm{C}$ in Ontario, and $22{ }^{\circ} \mathrm{C}$ in Quebec, so there was no association between diffuse flesh browning and high temperatures at 4 weeks before harvest, as with 'Bramley's Seedling' (Sharples, 1975). Variation in diurnal temperatures $60 \mathrm{~d}$ before harvest did not differ between the four locations (data not shown). Accumulated GDDs between full bloom and harvest for Maine, Minnesota, Ontario, and Quebec were $1123,1404,1103$, and 1089, respectively. Unlike 'Cripps Pink' fruit (James et al., 2010), there was no association between diffuse flesh browning and $<1200$ accumulated GDD between full bloom and harvest or variation in diurnal temperatures $60 \mathrm{~d}$ before harvest.

Based on the 2013 observations, temperature and diffuse flesh browning data were

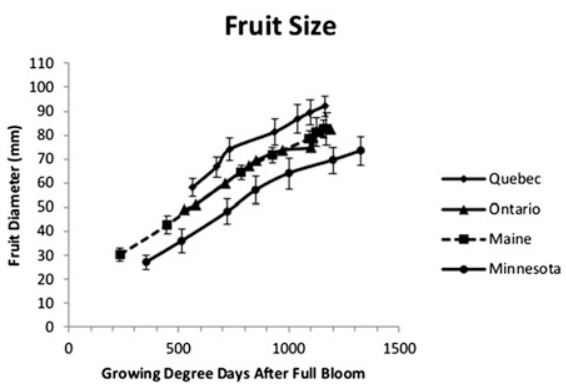

Fig. 5. Mean diameter of 'Honeycrisp' fruit grown in Maine, Minnesota, Ontario, and Quebec in 2013 as a function of growing degree-days (GDD) after full bloom. GDD at $60 \mathrm{~d}$ after full bloom in 2013 for Maine, Minnesota, Ontario, and Quebec were 586, 654, 578, and 465, respectively. Error bars represent \pm 1 sDs. collected for all locations for 2009-15. Table 2 presents a summary of diffuse flesh browning incidence and accumulated GDDs 60 DAFB for one orchard at each location occurring between 2009 and 2015. Generally, GDD accumulation of less than 500 at 60 DAFB resulted in some diffuse flesh browning. These data are similar to those for 'Cripps Pink', in which diffuse browning was more likely in Australian regions with less than 1100 GDD for the entire growing season, although Chilean fruit developed diffuse browning even if the orchards accumulated more than 1300 GDD for the season (Moggia et al., 2015). In 2010 and 2012 in Ontario, full bloom occurred early (May 5 and May 2, respectively, with usual full bloom in midMay), and in $201280 \%$ to $90 \%$ of the crop was lost due to frost.

Initial analyses of variance with one orchard per location (not including $\mathrm{PH} 1$ and PH2), year, and GDD 45, 60, 90, and 120 DAFB as variables indicated that only GDD 60 DAFB explained significant variation $(41 \%)$ in diffuse flesh browning. Further ANOVA using GDD 50, 55, 65, and 75 DAFB as variables resulted in $19 \%$ of the variation in 'Honeycrisp' diffuse flesh browning explained by GDD 60 DAFB $(P=0.03)$ and GDD 50 DAFB explaining another $12 \%$ of the variation $(P=0.08)$. Smaller contributions to variation in diffuse flesh browning were due to year, interaction between location and year, and GDD 55 DAFB (Table 3). Negligible effects on diffuse flesh browning variation were contributed by GDD 65 DAFB and GDD 75 DAFB. A linear model fitting 55 and 60 DAFB to diffuse flesh browning produced an adjusted $r^{2}=0.23(P=0.018)$, suggesting that GDD 55-60 DAFB are worth further examination with regard to diffuse flesh browning. Pearson's correlation tests resulted in a weak negative correlation between GDDs up to 60 DAFB and maximum diffuse flesh browning incidence $\left(r^{2}=\right.$ $-0.31, P=0.12)$. Diffuse flesh browning incidence was not correlated with GDDs up to 50 DAFB or 55 DAFB $(P=0.23$ and 0.36 , respectively). These analyses suggest that the critical time period for diffuse browning susceptibility is 50-60 DAFB.

In 2014, GDD at 60 DAFB were greater than 500 at all locations except Ontario (Table 2). In that season, temperatures dipped in both orchards of the commercial Minnesota operation at around 51 DAFB (Fig. 3). Average temperature dips were observed at all locations, including Ontario, between 55 and $60 \mathrm{DAFB}$, and these dips may increase diffuse flesh browning incidence if fruit are at a susceptible maturity when the temperature dips occur.

Moggia et al. (2015) suggest that GDH was a better predictor than GDD of diffuse browning in 'Cripps Pink' fruit, as it accumulates air temperature differently based on ranges, e.g., $4-25{ }^{\circ} \mathrm{C}, 25-36{ }^{\circ} \mathrm{C}$, and over $36{ }^{\circ} \mathrm{C}$. Anderson and Seeley (1992) used GDH accumulation in a model to predict cherry harvest maturity using 2 years of data from Michigan and 3 years of data from Utah. The model is based on a curvilinear accumulation of GDH and flower bud temperature. Although a strong correlation was reported for GDH accumulation and time of harvest, the model was not validated using other locations or published. It would be interesting to test the GDH model for diffuse browning in apple fruit with newer data from temperate locations and for cultivars other than 'Cripps Pink', especially for locations experiencing erratic temperatures where daily temperature accumulation does not follow a curvilinear pattern.

The strong effect of location in modeling based on weather conditions to predict 'Honeycrisp' fruit storage disorders is illustrated by soft scald models. Soft scald is a chilling injury disorder in which fruit peel develop "ribbons" of brown tissue. Using 7 years of data from Maine and 6 years of data from Ontario, soft scald incidence was negatively related to precipitation occurring 90-120 d from full bloom

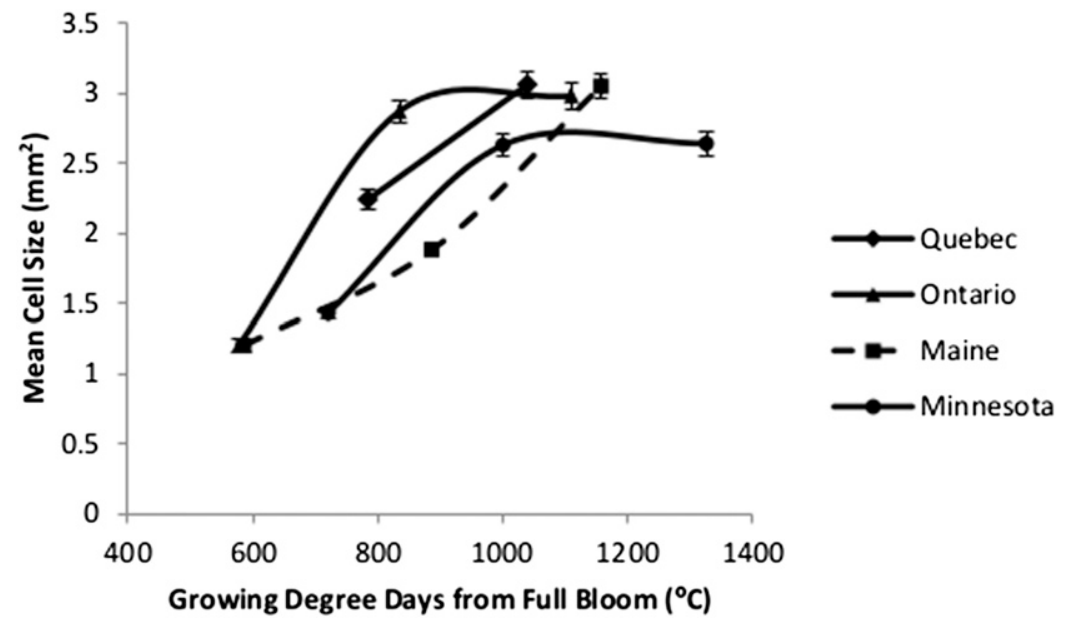

Fig. 6. Mean cell size of 'Honeycrisp' fruit harvested from Maine, Minnesota, Ontario, and Quebec in 2013. Growing degree-days at $60 \mathrm{~d}$ after full bloom in 2013 for Maine, Minnesota, Ontario, and Quebec were 586, 654, 578, and 465, respectively. Error bars represent sDs. 
Fresh Weight

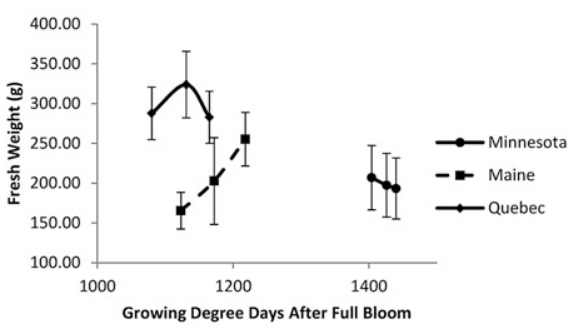

Soluble Solids Content

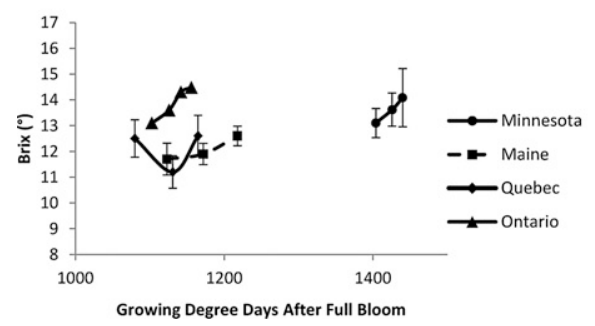

Starch Index

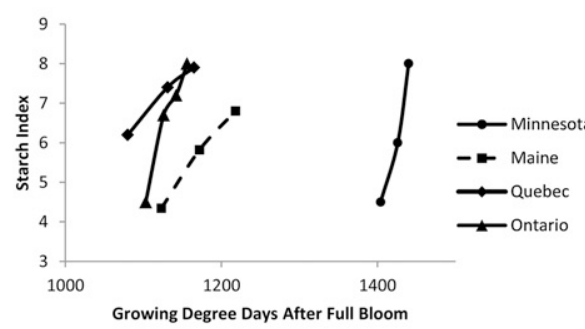

Titratable Acidity

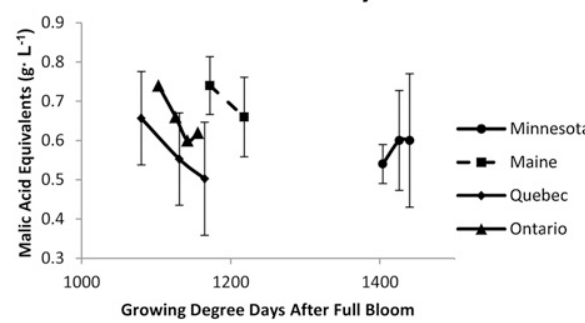

Firmness

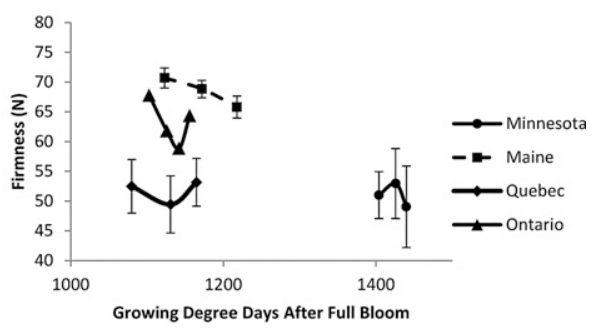

Dry Matter

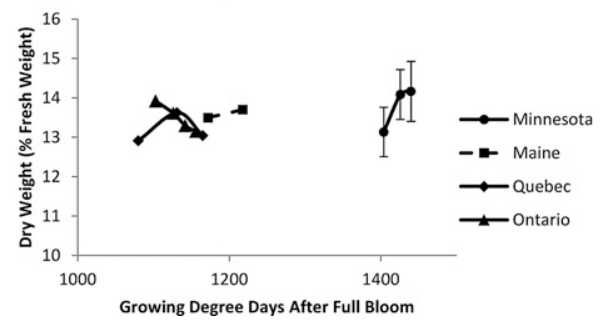

Fig. 7. Quality attributes of 'Honeycrisp' fruit from multiple harvests at orchards in Maine, Minnesota, Ontario, and Quebec in 2013. Error bars represent sDs. Fresh weight data were unavailable for the Ontario fruit.

(Moran et al., 2009). Using data from multiple years from Ontario, Quebec, and Nova Scotia, Lachapelle et al. (2013) developed a model predicting soft scald incidence, which included precipitation and temperatures at multiple fruit growth periods. This model accounted for $\approx 48 \%$ of the variation in soft scald incidence. Incorporating other factors, such as timing of optimum harvest, may improve predictive models, but there may be trade-offs among the different types of chilling disorders observed in 'Honeycrisp' fruit.

Fruit growth. To determine how 'Honeycrisp' fruit change during growth, measurements of fruit size were done in 2013 at Minnesota. These data (Fig. 4) indicated that at 55-60 DAFB, fruit were increasing linearly in size $\left(y=0.4871 x+16.263, r^{2}=0.96\right)$. The rate of growth of Minnesota fruit did not start to slow until $\approx 100$ DAFB. From a comparison of fruit size as a function of GDDs in 2013, it was observed that the rate of fruit growth did not slow in Maine and Quebec through harvest (at $\approx 1100$ GDD, Fig. 5). Fruit grown in Quebec were larger than those from the other locations.

The continuing growth of the Quebec fruit was also reflected in mean cell size of fruit of multiple harvests, but this observation was based on only two points (Fig. 6). The increase in mean cell size also did not seem to plateau in the Maine fruit. One interpretation of these data are that the Maine and Quebec fruit were still actively expanding (later maturing) at the time of harvest compared with the Minnesota and Ontario fruit. Although both the Maine and Quebec fruit were still increasing in size, the Maine fruit were of similar size to the Ontario fruit, whereas the Quebec fruit were largest of all locations. Fruit size has been reported as positively correlated with senescent browning (Prange et al., 2011). The combination of a slow

Table 4. Mean levels ( \pm SDS) of fructose, glucose, sorbitol, and sucrose measured in 'Honeycrisp' fruit from Maine, Minnesota, Ontario, and Quebec in 2013.

\begin{tabular}{lcccccc}
\hline Location & Harvest & $\begin{array}{c}\text { Fructose } \\
\left(\mathrm{mg} \cdot \mathrm{mL}^{-1}\right)\end{array}$ & $\begin{array}{c}\text { Glucose } \\
\left(\mathrm{mg} \cdot \mathrm{mL}^{-1}\right)\end{array}$ & $\begin{array}{c}\text { Sorbitol } \\
\left(\mathrm{mg} \cdot \mathrm{mL}^{-1}\right)\end{array}$ & $\begin{array}{c}\text { Sucrose } \\
\left(\mathrm{mg} \cdot \mathrm{mL}^{-1}\right)\end{array}$ & Fructose:sucrose \\
\hline Maine & 2 & $65.4 \pm 11.0$ & $7.0 \pm 2.6$ & $2.2 \pm 1.0$ & $52.6 \pm 7.6$ & 1.25 \\
& 3 & $70.0 \pm 13.4$ & $9.0 \pm 4.2$ & $4.2 \pm 3.6$ & $55.0 \pm 14.2$ & 1.29 \\
Minnesota & 1 & $76.4 \pm 12.0$ & $9.2 \pm 3.8$ & $2.6 \pm 1.2$ & $55.8 \pm 10.6$ & 1.38 \\
& 2 & $76.0 \pm 14.4$ & $8.0 \pm 6.8$ & $3.4 \pm 1.6$ & $59.0 \pm 12.0$ & 1.30 \\
Ontario & 3 & $77.6 \pm 9.6$ & $8.4 \pm 1.4$ & $4.4 \pm 2.8$ & $53.2 \pm 13.0$ & 1.47 \\
& 1 & $115.0 \pm 19.8$ & $15.6 \pm 6.4$ & $4.8 \pm 1.8$ & $76.6 \pm 22.6$ & 1.54 \\
& 2 & $122.0 \pm 22.0$ & $15.2 \pm 7.2$ & $8.0 \pm 4.4$ & $98.6 \pm 19.4$ & 1.25 \\
Quebec & 3 & $115.4 \pm 24.4$ & $15.2 \pm 5.6$ & $8.8 \pm 7.2$ & $94.2 \pm 24.8$ & 1.22 \\
& 1 & $54.4 \pm 9.9$ & $6.8 \pm 4.4$ & $2.4 \pm 1.6$ & $43.4 \pm 26.4$ & 1.29 \\
& 2 & $64.6 \pm 5.6$ & $8.8 \pm 1.8$ & $3.8 \pm 3.6$ & $52.0 \pm 9.6$ & 1.24 \\
\hline & 3 & $66.4 \pm 8.6$ & $7.8 \pm 5.2$ & $3.8 \pm 2.2$ & $58.2 \pm 13.2$ & 1.15 \\
\hline
\end{tabular}

Table 5. Mean levels ( \pm SDs) of fructose, glucose, sorbitol, and sucrose measured in 'Honeycrisp' fruit from a commercial orchard in Minnesota in 2014 and 2015.

\begin{tabular}{lcccccc}
\hline Yr & Orchard & Browning & $\begin{array}{c}\text { Fructose } \\
\left(\mathrm{mg} \cdot \mathrm{mL}^{-1}\right)\end{array}$ & $\begin{array}{c}\text { Glucose } \\
\left(\mathrm{mg} \cdot \mathrm{mL}^{-1}\right)\end{array}$ & $\begin{array}{c}\text { Sorbitol } \\
\left(\mathrm{mg} \cdot \mathrm{mL}^{-1}\right)\end{array}$ & $\begin{array}{c}\text { Sucrose } \\
\left(\mathrm{mg} \cdot \mathrm{mL}^{-1}\right)\end{array}$ \\
\hline 2014 & 1 & None & $97.6 \pm 9.7$ & $17.6 \pm 3.2$ & $3.6 \pm 1.1$ & $61.8 \pm 14$ \\
& 1 & Brown & $81.8 \pm 15.2$ & $13.0 \pm 6.5$ & $5.9 \pm 2.6$ & $64.2 \pm 4.3$ \\
& 2 & None & $108.6 \pm 5.7$ & $21.7 \pm 1.3$ & $5.3 \pm 2.0$ & $62.3 \pm 19.3$ \\
& 2 & Brown & $83.5 \pm 11.8$ & $13.3 \pm 3.4$ & $4.4 \pm 0.6$ & $67.0 \pm 7.7$ \\
2015 & 1 & None & $69.9 \pm 6.2$ & $9.1 \pm 2.0$ & $4.1 \pm 0.9$ & $57.9 \pm 9.3$ \\
& 1 & Brown & $69.6 \pm 7.6$ & $10.0 \pm 1.6$ & $4.4 \pm 2.6$ & $59.2 \pm 8.5$ \\
& 2 & None & $71.3 \pm 6.4$ & $9.8 \pm 2.5$ & $5.7 \pm 2.1$ & $61.1 \pm 7.7$ \\
& 2 & Brown & $72.6 \pm 3.8$ & $9.1 \pm 1.1$ & $3.5 \pm 1.3$ & $55.9 \pm 8.3$ \\
\hline
\end{tabular}

maturity rate with large fruit size could account for some of the variation in observed diffuse flesh browning not explained by low GDDs 60 DAFB.

Maturity at harvest. Other than fresh fruit weight, there were no differences in quality attributes at harvest between fruit grown at the different locations (Fig. 7). Quebec fruit weighed more at harvest than fruit from the other locations. Minnesota fruit experienced greater accumulated GDD than fruit at the other locations. The lower GDDs experience by the Quebec fruit during active growth did not affect fruit quality at harvest. Firmness and TA of Quebec fruit were lower than that of Maine or Ontario, but comparable to that of Minnesota, fruit. There were no differences in starch index, SSC, or dry matter between fruit of the four locations, and accumulated GDDs did not affect these attributes. Diffuse flesh browning incidence was greatest for the last harvest in Quebec (20\% compared with $7 \%$ for the earlier harvests), but based on the measured quality attributes, there was no difference in maturity between fruit from Quebec and the other locations. However, none of the measured quality attributes are 
useful in determining 'Honeycrisp' fruit maturity (Watkins et al., 2005).

Carbohydrate content. To test the hypothesis that sugar metabolism is disturbed in 'Honeycrisp' fruit that develop flesh browning, sugar levels of stored fruit from the 2013 experiment, and from the 2014 and 2015 harvests at the commercial Minnesota orchard, were measured. In 2013, the Ontario fruit had the greatest levels of all sugars measured (Table 4). Quebec fruit had the lowest fructose levels, although not different from that of the other locations. Diffuse flesh browning incidence was not correlated with any of the measured sugars or between diffuse flesh browning incidence and ratios of fructose, glucose, or sorbitol to sucrose $(P>0.17)$. When data from two other orchards, one each in Maine and Ontario, were included in the analyses with the original four locations, there was a negative correlation between diffuse flesh browning and the ratio of fructose to sucrose $\left(r^{2}=-0.45, P=0.08\right)$. This was surprising, given that differences in ratios between locations and harvests were very small. Fruit used to assess browning incidence were not the same fruit used for carbohydrate analyses, as fruit were assessed for browning after storage at each growing location, and different fruit were sent to Minnesota for sugar analyses. This may account for the lack of correlation obtained with data from the original four locations. To obtain more direct evidence of differences in sugar content with diffuse flesh browning, carbohydrate analyses were done on fruit with and without (unaffected) browning from the commercial orchard in Minnesota.

In 2014, fructose and glucose levels were lower in browned compared with unaffected fruit (Table 5). Welch two-sample $t$ tests resulted in differences in fructose $(P=$ $0.002)$ and glucose $(P=0.004)$ levels, fructose to sucrose ratio $(P=0.015)$, and glucose to sucrose ratio $(P=0.008)$ between unaffected and browned fruit. Ratios of fructose to sucrose and glucose to sucrose were lower in brown compared with unaffected fruit in 2014 (Fig. 8). However, there were no differences between unaffected and browned fruit in fructose or glucose levels, or in the ratios of fructose or glucose to sucrose in 2015 fruit. One possible explanation is that sugar metabolism in unaffected 2015 fruit may have been disturbed because temperatures 50-60 DAFB were low (60 DAFB GDD <500), such that fruit scored as unaffected may have developed browning if scored after another month in storage. Due to the binomial sampling of 2014 and 2015 fruit for browning, modeling could not be done to determine if carbohydrate content could be used to predict browning. The results from 2013 and 2014, however, provide support for the hypothesis that 'Honeycrisp' fruit exhibiting flesh browning have experienced disruptions in fructose and glucose metabolism. Presumably these disruptions occur when 'Honeycrisp' fruit cells are actively expanding (Stanley et al., 2000) and exposed to low temperatures, around the critical 55-60 DAFB timespan, although this speculation needs to be tested in future studies.

Elemental analyses. $t$ tests indicated that magnesium $(P=0.03)$ and potassium $(P=0.04)$ levels, as well as the ratio of magnesium to phosphorus $(P=0.01)$, were greater in 2009 in browned Michigan and Minnesota fruit compared with unaffected fruit. There was no difference in calcium, manganese, or phosphorus concentrations between unaffected and brown fruit (Table 6)

Similarly, fruit harvested in 2014 from the commercial orchard in Minnesota that exhibited browning had higher magnesium levels $(P=0.003)$ and ratios of magnesium to phosphorus $(P=0.0003)$ than unaffected fruit (Table 7). However, phosphorus $(P=0.03)$, but not potassium, levels differed between brown and unaffected fruit. High magnesium and potassium are associated with flesh breakdown in 'Gala' fruit (Johnson, 2000), but not with 'Cox's Orange Pippin', in which high magnesium levels delay and reduce
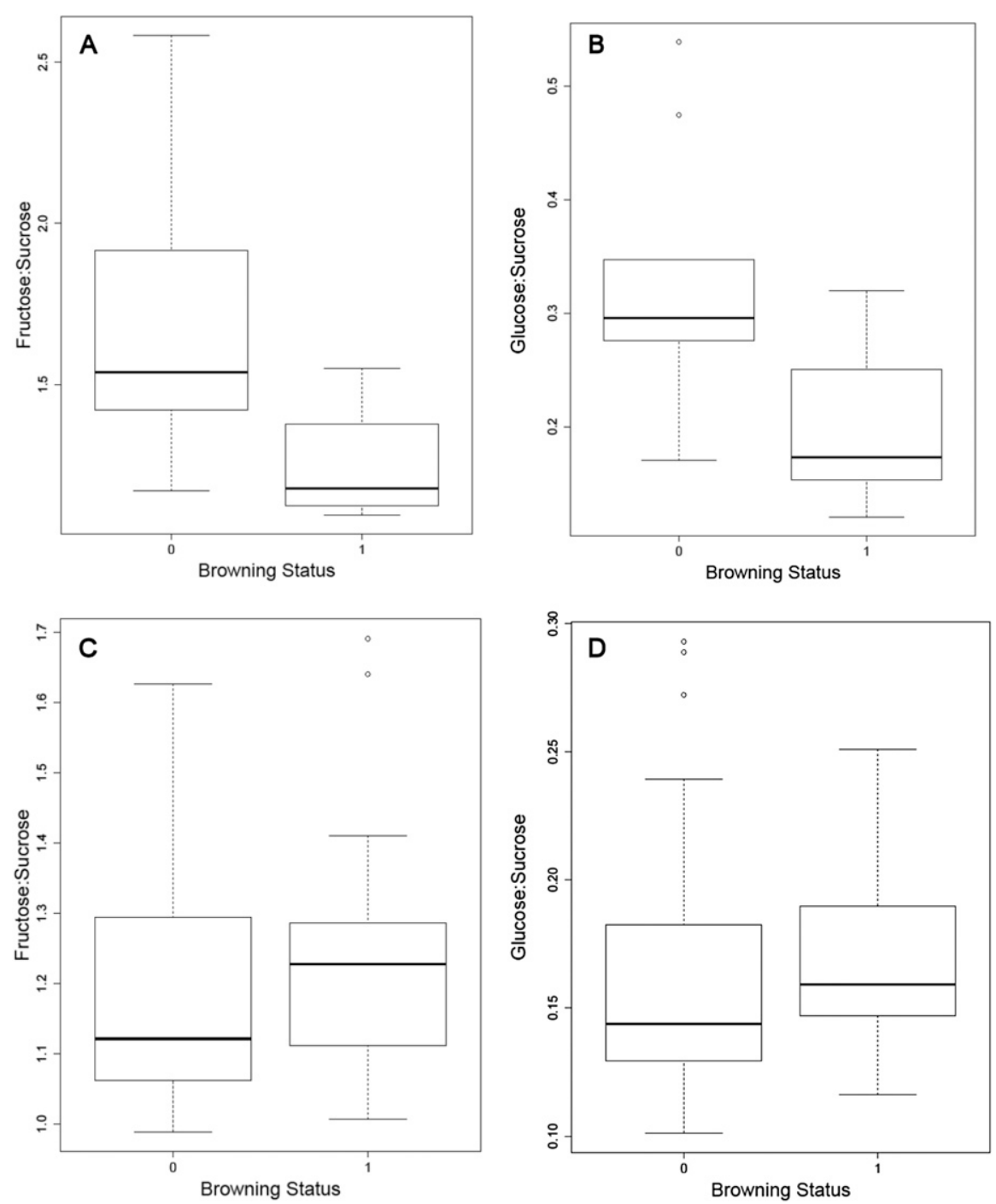

Fig. 8. Ratios of fructose (A and C) or glucose (B and D) to sucrose in 2014 (A and B) and 2015 (C and D) fruit that were unaffected ( 0 on $x$ axis) or brown ( 1 on $x$ axis) from the Minnesota commercial orchard. Boxplots derived from $\mathrm{n}=10$ fruit per year and browning status. 
Table 6. Mean elemental content (mg.kg ${ }^{-1}$ dry weight) of fruit harvested in 2009 from orchards in Michigan and Minnesota, with and without diffuse flesh browning.

\begin{tabular}{llccccccccccc}
\hline State & Browning & $\mathrm{B}$ & $\mathrm{Ca}$ & $\mathrm{Cu}$ & $\mathrm{Fe}$ & $\mathrm{K}$ & $\mathrm{Mg}$ & $\mathrm{Mn}$ & $\mathrm{Na}$ & $\mathrm{P}$ & $\mathrm{Zn}$ & $\mathrm{Mg}: \mathrm{P}$ \\
\hline Michigan & None & 14.0 & 219 & 1.6 & 6.9 & 6,673 & 250 & 3.7 & 27.9 & 529 & 2.4 & 0.47 \\
& Brown & 11.7 & 204 & 1.5 & 7.1 & 6,804 & 262 & 3.4 & 25.0 & 515 & 1.7 & 0.51 \\
Minnesota & None & 19.6 & 223 & 1.5 & 4.1 & 4,611 & 179 & 1.7 & 28.3 & 501 & 1.5 & 0.36 \\
& Brown & 20.2 & 249 & 1.4 & 5.1 & 5,987 & 226 & 2.4 & 30.6 & 480 & 1.1 & 0.47 \\
& $P$ value & 0.71 & 0.59 & 0.27 & 0.34 & 0.04 & 0.03 & 0.65 & 0.91 & 0.5 & 0.30 & 0.015 \\
& & & & 0.34 & &
\end{tabular}

$P$ values are from Welch two-sample $t$ tests of data aggregated from the two states.

Table 7. Mean elemental content (mg. $\mathrm{kg}^{-1}$ dry weight) of fruit from 2014 commercial orchard in Minnesota with and without diffuse flesh browning.

\begin{tabular}{lccccccccccc}
\hline Browning & $\mathrm{B}$ & $\mathrm{Ca}$ & $\mathrm{Cu}$ & $\mathrm{Fe}$ & $\mathrm{K}$ & $\mathrm{Mg}$ & $\mathrm{Mn}$ & $\mathrm{Na}$ & $\mathrm{P}$ & $\mathrm{Zn}$ & $\mathrm{Mg}: \mathrm{P}$ \\
\hline None & 18.4 & 245 & 2.0 & 6.2 & 5,053 & 250 & 3.3 & 16.6 & 663 & 1.3 & 0.38 \\
Brown & 17.1 & 246 & 1.4 & 5.2 & 4,677 & 297 & 2.9 & 27.6 & 584 & 1.6 & 0.51 \\
$P$ value & 0.295 & 0.98 & 0.014 & 0.22 & 0.24 & 0.003 & 0.06 & 0.13 & 0.03 & 0.18 & 0.0003 \\
\hline
\end{tabular}

$P$ values are from Welch two-sample $t$ tests.

bloom, could increase risk of diffuse flesh browning in 'Honeycrisp' fruit. Severe dips in orchard temperature, even with average spring temperatures, could also increase risk of diffuse flesh browning development. Large fruit are especially susceptible to this disorder. A good understanding of the environmental conditions that predispose apple fruit to different types of flesh browning would permit better forecasting of risk for farmers.

Electron microscopy to determine if cell collapse occurs with diffuse flesh browning in 'Honeycrisp' as with 'Cripps Pink' may be informative in furthering understanding of the disorder. Because calcium was not correlated with 'Honeycrisp' diffuse flesh browning, cell collapse may not occur in 'Honeycrisp', as it does in 'Cripps Pink' (James and Jobling, 2009). Presumably the compounds directly responsible for flesh browning are oxidized phenolics, released when cells collapse. However, 'Honeycrisp' fruit contain similar amounts of phenolics (Matthes and Schmitz-Eiberger, 2009; Zhang et al., 2010) and polyphenol oxidase activity (Burke, 2010) compared with other apple cultivars, yet its flesh does not brown quickly when cut (Fig. 1). Leisso et al. (2015) examined the metabolic profiles of 'Honeycrisp' fruit with soggy breakdown, comparing affected and unaffected areas of the same fruit or fruit with soggy breakdown to healthy fruit. They found that starch and glucose metabolism are upregulated in healthy compared with scalded fruit, although glycolysis or gluconeogenesis is upregulated in symptomatic compared with healthy or asymptomatic fruit. Also, symptomatic areas have fewer antioxidant compounds, such as $\alpha$-tocopherol and violaxanthin, as well as the precursors of condensed tannins, catechin, and epicatechin, than do asymptomatic areas or healthy fruit. Similarities and differences in etiologies of soggy breakdown, carbon dioxide-induced flesh browning, radial flesh browning, and diffuse flesh browning have not yet been delineated. Further clarification of the different types of flesh browning, taking into account severity and combined disorders, occurring in 'Honeycrisp' fruit is needed to fully understand the processes that lead to these storage disorders. Such an understanding will allow researchers to improve predictive models to help apple growers avoid these costly problems.

\section{Literature Cited}

Anderson, J.L. and S.D. Seeley. 1992. Modelling strategy in pomology: Development of the Utah models. Acta Hort. 313:297-306.

Berüter, J., M.E. Studer Feusi, and P. Rüedi. 1997. Sorbitol and sucrose partitioning in the growing apple fruit. J. Plant Physiol. 151:269276.

Blanpied, G.D. and K.J. Silsby. 1992. Predicting harvest date windows for apples. Cornell Cooperative Ext. Info. Bul. 221.

Burke, A.E. 2010. Quantifying flesh browning, polyphenoloxidase, total phenolic content and vitamin $C$ in select apple varieties and progeny. $\mathrm{PhD}$ Diss, Cornell Univ., Ithaca.

Contreras, C., N. Alsmairat, and R. Beaudry. 2014. Prestorage conditioning and diphenylamine improve resistance to controlled-atmosphererelated injury in 'Honeycrisp' apples. HortScience 49:76-81.

DeLong, J.M., R.K. Prange, P.A. Harrison, C.G Embree, D.S. Nichols, and A.H. Wright. 2006. The influence of crop-load, delayed cooling and storage atmosphere on post-storage quality of 'Honeycrisp' TM apples. J. Hort. Sci. Biotechnol. 81:391-396.

Ehsani-Moghaddam, B. and J.R. DeEll. 2013. Relationships among postharvest ripening attributes and storage disorders in 'Honeycrisp' apple. Fruits 68:323-332.

Elgar, H.J., C.B. Watkins, and N. Lallu. 1999 Harvest date and crop load effects on a carbon dioxide-related storage injury of 'Braeburn' apple. HortScience 34:304-309.

Faust, M.C.S. and M.W. Williams. 1969. Disorders of carbohydrate metabolism of apples (watercore, internal breakdown, low temperature and carbon dioxide injuries). Bot. Rev. 35:168-194.

Fidler, J.C. and C.J. North. 1970. Sorbitol in stored apples. J. Hort. Sci. 45:197-204.

Jackson, J.E., J.W. Palmer, M.A. Perring, and R.O. Sharples. 1977. Effects of shade on the growth and cropping of apple trees. III. Effects on fruit growth, chemical composition and quality at harvest and after storage. J. Hort. Sci. 52:267-282.

James, H.J. and J.J. Jobling. 2009. Contrasting the structure and morphology of the radial and diffuse browning disorders and $\mathrm{CO}_{2}$ injury of 'Cripps Pink' apples. Postharvest Biol. Technol. 53:36-42.

James, H., J. Jobling, D. Tanner, S. Tustin, and I. Wilkinson. 2010. Climatic conditions during growth relate to risk of Pink Lady ${ }^{\mathrm{TM}}$ apples developing flesh browning during storage. Acta Hort. 857:197-203.

Johnson, D.S. 2000. Mineral composition, harvest maturity and storage quality of 'Red Pippin', 'Gala', and 'Jonagold' apples. J. Hort. Sci. Biotechnol. 75:697-704.

Johnson, D.S. and N. Yogaratnam. 1978. The effects of phosphorus sprays on the mineral composition and storage quality of Cox's Orange Pippin apples. J. Hort. Sci. 53:171-178.

Lachapelle, M., G. Bourgeois, J. DeEll, K.A. Stewart, and P. Séguin. 2013. Modeling the effect of preharvest weather conditions on the incidence of soft scald in 'Honeycrisp' apples. Postharvest Biol. Technol. 85:5766.

Lau, O.L. 1998. Effect of growing season, harvest maturity, waxing, low $\mathrm{O}_{2}$ and elevated $\mathrm{CO}_{2}$ on flesh browning disorders in 'Braeburn'apples. Postharvest Biol. Technol. 14:131-141.

Leisso, R.S., D.A. Buchanan, J. Lee, J.P. Mattheis, C. Sater, I. Hanrahan, C.B. Watkins, N. Gapper, J.W. Johnston, R.J. Schaffer, M.L.A.T.N Hertog, B. Nicolaï, and D.R. Rudell. 2015. Chilling-related cell damage of apple (Malus $\times$ domestica Borkh.) fruit cortical tissue impacts antioxidant, lipid and phenolic metabolism. Physiol. Plant. 153:204-220.

Liu, Y., Y. Ying, H. Yu, and X. Fu. 2006. Comparison of the HPLC method and FT-NIR analysis for quantification of glucose, fructose, and sucrose in intact apple fruits. J. Agr. Food Chem. 54:2810-2815.

Matthes, A. and M. Schmitz-Eiberger. 2009. Polyphenol content and antioxidant capacity of apple fruit: Effect of cultivar and storage conditions. J. Appl. Bot. Food Qual. 82:152157.

Meheriuk, M., R.K. Prange, P.D. Lidster, and S.W. Porritt. 1994. Postharvest disorders of apples and pears. Agr. Can. Publ. 1727/E.

Moggia, C., M. Pereira, J.A. Yuri, C.A. Torres, O. Hernández, M.G. Icaza, and G.A. Lobos. 2015. Preharvest factors that affect the development of internal browning in apples cv. Cripp's Pink: Six years compiled data. Postharvest Biol. Technol. 101:49-57.

Moran, R.E., J.R. DeEll, and W. Halteman. 2009. Effects of preharvest precipitation, air temperature, and humidity on the occurrence of soft scald in 'Honeycrisp' apples. HortScience 44:1645-1647.

Perring, M.A. and W. Płocharski. 1975. Proportions of calcium, magnesium, phosphorus and potassium extractable by water or ethanol from apple fruit tissue, in relation to length of storage, orchard factors and storage disorders. J. Sci. Food Agr. 26:1807-1817.

Prange, R., J. DeLong, D. Nichols, and P. Harrison. 2011. Effect of fruit maturity on the incidence of bitter pit, senescent breakdown, and other post-harvest disorders in 'Honeycrisp'тм apple. J. Hort. Sci. Biotechnol. 86:245-248.

RStudio Team. 2015. RStudio: Integrated Development for R. RStudio, Inc., Boston, MA. 15 Mar. 2016. <http://www.rstudio.com/>.

Sharples, R.O. 1975. Influence of climate on the storage quality of pome fruits, p. 113-124. In: C. Pereira (ed.). Climate and the Orchard. Commonwealth Agricultural Bureaux, Farnham Royal, UK. 
Smock, R.M. 1997. Nomenclature for internal storage disorders of apples. HortScience 12:306-308.

Stanley, C.J., D.S. Tustin, G.B. Lupton, S. Mcartney, W.M. Cashore, and H.N. De Silva. 2000. Towards understanding the role of temperature in apple fruit growth responses in three geographical regions within New Zealand. J. Hort. Sci. Biotechnol. 75:413-422.
Telias, A., E. Hoover, C. Rosen, D. Bedford, and D. Cook. 2006. The effect of calcium sprays and fruit thinning on bitter pit incidence and calcium content in 'Honeycrisp' apple. J. Plant Nutr. 29:1941-1957.

Watkins, C.B., M. Erkan, J.F. Nock, K.A. Iungerman, R.M. Beaudry, and R.E. Moran. 2005. Harvest date effects on maturity, quality, and storage disorders of 'Honeycrisp' apples. HortScience 40:164-169.
Webster, D.H. and P.D. Lidster. 1986. Effects of phosphate sprays on McIntosh apple fruit and leaf composition, flesh firmness and susceptibility to low-temperature disorders. Can. J. Plant Sci. 66:617-626.

Zhang, Y., P. Li, and L. Cheng. 2010. Developmental changes of carbohydrates, organic acids, and phenolic compounds in 'Honeycrisp' apple flesh. Food Chem. 123:1013-1018. 